\title{
THE EXPERIMENTAL EFFECT OF ARTIFICIAL AIR IONIZATION ON SOME NONSPECIFIC PARAMETERS OF IMMUNE SYSTEM OF WISTAR RATS
}

\author{
Iu. Simionca, L.Enache \\ National Institute of Rehabilitation, Physical Medicine and Balneoclimatology
}

\section{INTRODUCTION}

A special place in the category of balneometeorological factors is occupied by the natural air ionization.

The first observations on the existence of gaseous ions in the air have been made since the earrly twentieth century (German physicist- Landerburg and French- Panthenier), and then repeated and through after the 50 of various collective (including French physicist J. Bricard, from University of Paris). They highlighted the link between low ion content in the air and atmosphere micropopulation and the fact that the lack almost daily of a minimum amount of a small negative ions of $\mathrm{O}_{2}$ from places of daily activities represent a case of occurrence of unavoidable disturbance on health status, often severe.

A large number of subsequent research have confirmed the link between this electrical paramater of air and a large biological effects manifested at various stages in world living organization, from cellular level to the body. These influences are possible because living organisms manifests itself a very large number of phenomena such

as electricity, with essential biological role (e.g, biochemical reactions, transmembrane transport of $t$ he substance, the nervous impulse propagation and others). However, based on these findings, it was concluded that under the artificially ionized atmosphere by controlled exposure, can provide relatively easy con ditions for recovery of these environmental factors by induction a favorable therapeutic treatment on body. The ions influence start mainly from alveloi and in a lesser extent from skin.

The excess of negative electric charges carried by ions interact with both sensory nerveendings in the alveoli, and a series of blood components (RBC, some colloids), changing directly their electrical properties and stability and $i$ ndirectly affecting other of various organic

structures through numerous biochemical reactions that contribute to increased metabolism. The studies and researches conducted till now indicate the existence of numerous biological effects. Although some investigation on the effects of negative and positive air ionization have been done during the years 1950-60 (F.Verzar, 1955; A.P.Krueger, R.F Smith and Ing Gan Go, 1957;
A.P.Krueger, R.F Smith, 1958, 1960; L. L.Vassiliev , 1960; A. L. Tchijevski, 1963) this problem is current because of the development of different technologies which affect the environment (Ardelean I., Barnea M., 1972, Enache L. ş coaut., 1972 - 2005; Simionca Iu.M., Gorbenko P.P., Gorbenko V.P., 1994 - 1995);

The studies on the effect of negative and positive air ionization on the nonspecific resistance of the organism and immune status whose decrease may cause various chronic infections with normal, conditionally pathogenic microflora or latent viruses (Pierson, 1993; Taylor et al., 1997) have an special interest.

The action of the negative natural air ions on the human and animal organism is a positive factor (Boulatov, P. C., 1968 ; Jones D.P. and al., 1976; Simionca Iu.M., Gorbenko P.P., Gorbenko V.P., 1980; Botea Simona şi al., 2005; Enache Liviu, Hoteteu M., Rogojan Rodica, Simionca Iu. şi al. , 2005; Georgescu Ileana, Enache Liviu, Simionca Iu. şi al., 2005; Tarniţă Georgeta şi al., 2005 ).

Experimentally was found that in cases with insufficient negative air ions in the body of laboratory animal the pathogens persist in different cavities of organs, as a result of disruption of the phagocytosis process (Tchijevski A. L., 1963 ).

It is known that natural negative air ionization does't have high values, with variations of about 200 to 15,000 particles $/ \mathrm{cm}^{3}$.

The emergence of opportunities to use artificial air ionization in research and practical allowed developing and launching further studies, including microbiology, infectious-inflammatory process, but also immunology studies, although it should be mentioned that immune investigations were often humoral and from the cellular spectrum -some on the phagocytosis process on the immune status of animals and humans was rare (Kornblueh, I. H.,1973; Laza, V.,1996 ).

From the point of negative air ionizatin, effects on microorganisms and inflammatory process the studies of AP. Krueger and collaborators have a particularly interest (1957- 1985), Marin et al., 1989)

Are described some investigation about the beneficial effect of negative air ionization on the inflamed experimentally induced injuries for dogs and cats (A.K.Guman şi Z.P. Tsapotsnikova,1959), as well as chronic injuries of humans (Minehart J. 
R. and al., 1961; F.G.Portnov and al.,1971; Makela Paavo and al., 1979).

Some studies was dedicated to the desensitizing effect of body under the action of negative air ions (Boulatov, P. C., 1968).

In Antarctica was found a positive effect of negative air ionization on the cellular immune system ( Williams, D.L., Climie, A., Muller, H.K. and Lugg, D.J. 1986). The negative air ionization is one of the components of the therapeutic mechanism of caves and salt mines microclimate (Simionca Iu.and al., 1997, 1999, 2005; Enache Liviu, Filipescu C., Simionca Iu. (Ghe.) şi al., 2005).

Positive air ions cause depression, insomnia, headaches, rashes, acute asthma attacks, affects the normal activity of the thyroid glands (Gualtierotti, 1968), an opposite effect of negative air ions (Livanova et al., 1999).

\section{MATERIALS AND METHODS USED FOR THE STUDY .}

To achieve the objectives of study were selected a total of 47 laboratory white line Wistar rats (Wistar Rats - WR), male, divided into three series:

- Serie I included 3 homogeneous lots, as follows: Lot 2 - composed of seven such animals without injury, uninfected and subjected to negative air ionization of about 15,000 particles $/ \mathrm{cm}^{3}$ concentration; lot 5 - of 9 animals with injuries of skin surface to which equal to $3.0 \mathrm{~cm}^{2}$ infected with Staphylococcus aureus, unionized, Lot 6 -of 9 animals with injuries of $3.75 \mathrm{~cm}^{2}$ infected with that micoorganisms ;

- serie II - 3 homogeneous lots: lot 1 - animals without injury, uninfected and without ionization (7 animals); lot 3 - animals without injury, uninfected and subjected to negative air ionisation of about 230.000 particles $/ \mathrm{cm}^{3}$ concentration (7 animals); lot 7- animals without injury of $16,3 \mathrm{~cm}^{2}$, infected with that microorganism and subjected to negative air ionization of about 230.000 particles $/ \mathrm{cm}^{3}$ concentration ( 9 animals); lot 9 - animals with injury of $16,3 \mathrm{~cm}^{2}$, infected and unionized (7animals); lot 10 - animals with injury of 20,1 $\mathrm{cm}^{2}$, infected, unionized, investigated after 10 days from infection and the development of inflammatory skin infectious process ( 7 animals) ;

- serie III - with 2 homogeneous lots: lot 4 animals with injury of $13,6 \mathrm{~cm}^{2}$, uninfected, subjected to positive air ionization of about 230.000 particles $/ \mathrm{cm}^{3}$ ( 7 animale); lot 8 - animals with injury of $13,6 \mathrm{~cm}^{2}$, infected, subjected to the same Table 1. Lots of WR white rats subjected study concentration and polarity of air ionization ( 9 animals).

The animals were anesthetized with pentobarbital at a concentration of $12 \mathrm{mg} / \mathrm{ml}$ heparin solution and then on the back of them were caused a injury by scraping who was infected with a pure culture of Staphyilococcus aureus of $109 / \mathrm{ml}$ etiologic concentration, thus was induced the infectious skin inflammation process (PII).

From the 2nd day after the start of inflammation process of series I and day 4 respectively for series II, lots were subjected to ions for 4 hours / day for three weeks, animals were kept under standard conditions of biobase.

Table 1 presents: the subject WR lots of the study, the polarity and concentration of artificial air ions generated for application to laboratory animals in the experiment, the average area of skin injury and the observations on inflammation with conditionally pathogenic microorganisms Staphylococccus aureus .

Air ionization of skin area with or without PII was performed using an ion generator for generating possibilities 15000-230000 negative ion / positive / $\mathrm{cm}^{3}$

\section{Were performed these tests on the laboratory animals (WR):}

1. The process of phagocytosis of polymorphonuclear granulocytes (PMN).

a. Phagocytic activity against Staph. aureus / number of phagocytic cells (\% and NX10*9/1 blood);

b. Number of phagocytized microbial cells (Staph.aureus);

c. Killing Effect / Number of microbial cells in decay phasefrom phagocit cytoplasm (\%).

For performing phagocytosis test was used pure PMN granulocyte cells suspension, obtained by sedimentation forced method in ficoll- omnipac gradient with density 1077; pure culture of Staph. aureus was standardized after concentration. Phagocytosis test was performed according to the EAKost methodology (1975), with methodical recommendations proposed by S. Wood, A. White (1978),

EFCernuşenko et al. (1981, 1986), Gabay JE. (1988) and A. Olinescu Angela Dolganiuc (2001). Bades with the test preparations were stained after Giemsa method, and read by photon microscope immersion microscopy. 


\begin{tabular}{|c|c|c|c|c|c|}
\hline $\begin{array}{l}\text { Name Lot } \\
\text { WR }\end{array}$ & $\begin{array}{l}\text { Marking } \\
\text { lots }\end{array}$ & Ionization type & $\begin{array}{l}\text { Particules- } \\
\text { ions } \\
\text { concentrati } \\
\text { on }\end{array}$ & $\begin{array}{l}\text { WR with and } \\
\text { without injuries }\end{array}$ & $\begin{array}{c}\text { Specific characterization of } \\
\text { WR lots }\end{array}$ \\
\hline S2L1 & & Without ionization & 0 & Without injury & Control lot \\
\hline S1L2 & & Negative & 15.000 & Without injury & Uninfected \\
\hline S2L3 & & Negative & 230.000 & Without injury & Uninfected \\
\hline S1L5 & & Without ionization & 0 & 3.0 & Infected with Staph. aureus \\
\hline S2L9 & & Without ionization & 0 & 16.3 & $\begin{array}{c}\text { Infected with Staph. } \\
\text { aureus, }\end{array}$ \\
\hline S2L10 & & Without ionization & 0 & 20.1 & $\begin{array}{c}\text { Infected with Staph. } \\
\text { aureus;investigated after } 10 \\
\text { days }\end{array}$ \\
\hline S1L6 & & Negative & 15.000 & 3.75 & Infected with Staph. aureus \\
\hline S2L7 & & Negative & 230.000 & 16.3 & Infected with Staph. aureus \\
\hline S3L4 & & Positive & 230.000 & 13.6 & uninfected \\
\hline S3L8 & & Positive & 230.000 & 13.6 & Infected with Staph. aureus \\
\hline
\end{tabular}

Evaluation of oxygen-dependent bactericidal function of PMN granulocytes (oxidative metabolism of phagocytes) - by NBT test (Blaunitroso-tetrazolium test) which is based on the Blau-tetrazolium reduction of substance in the cells by the action of insoluble formasan NADF oxidase. NBT test was performed according to method B. Park et al., (1968) and methodical recommendations of E.F. Cernuşenko. (1988). The result was read by photon microscopy with immersion and presented by the number of granulocytic cells formasan positive PMN ( $\%$ and NX10* $9 / 1$ blood).

3. For immunological tests on populations and subpopulations of lymphocytes, including pure were obtained lymphocyte suspension cells using the centrifuge technique and methodology of heparinized blood in Ficoll gradient (Feinchemie Approach, Austria) and Omnipac (Maging Nicomedia, Norway) d. 1077 by the method C. Hartman et al. (1971), C.C. Patric, CDGrabar and CBLoadholt (1976) and methodological recommendations of E.F. Cernuşenko et al. (1988) and A. Olinescu Angela Dolganiuc (2001), C. Bar. (2002).

4. The assessment test cells of $\mathrm{T}$ lymphocytes from Wistar rats was performed after the methodological of M. Jondal, G. Klein (1973) and J. Bach et al. (1974) by test E-Rosette forming cells - E-RFC (rosette-forming lymphocyte cells with sheep erythrocytes - "E-CLFR" - the classic test for assessing the T-cell) E-test CLFR, $29 \mathrm{C}$ and (concentration of lymphocytes $\mathrm{T}$ $29 \mathrm{C}^{\circ}$ - T-helpers, $\%$ and NX10 * 9 / 1 blood) - cells forming rosettes "high and low affinity " (Helper and suppressor), and test E-CLFR, $45^{\circ} \mathrm{C}$ (45 C concentration and $\mathrm{T}$ lymphocytes - cytotoxic and NX10\% 9 / 1 blood), using the methodology of the test micromethod recommended by Iu.Simionka (1985, 1989) and E.F. Cernuşenko. (1988) and A. Olinescu Angela Dolganiuc (2001). Reading the results was performed by photon microscopy after Giemsa stained blade taking into account the methodological recommendations J. Evans et al (1975).

5. The test of lymphocytes blast transformation (TTLB) in phytohaemagglutinin activation. The test was performed according to classical methodologies (by F. Bach, K. Hirschorn, 1963), adapted for working with pure cultures of lymphocytes (after Iu.Simionca, 1985, 1989) and morphological evaluation of activated lymphocytes and transformed into blasts, the blades was read by photon microscope.

\section{RESULTS}

The figures below (figures 1-5) present the results of evaluation of antibiotic resistance factors on the animal organism (test neutrophil phagocytosis of polymorphonuclear neutrophils and neutrophil formasan tests for positive / nitroso-blautetrazolium test).

It was noted that the action of negative air ionization of 15,000 and 300,000 particles $/ \mathrm{cm}^{3}$ on WR lots with injury and uninfected (lots S1L2, S2L3) there were no significant changes in relative concentration (\%) of phagocytes.

With the development of inflammation in those animals with infected injuries but unionized (lots S2L9, S2L10) was found a tendency of decreasing the relative number of phagocytic PMN and the WR with uninfected and infected injuries but 
subject to positive air ionization of 230,000 particles $/ \mathrm{cm}^{3}$ (lots S3L4 and S3L8) - a substantial decrease in relative number of phagocytic cells ( $\mathrm{P}$ $<0.05)$.

From point of air ionization effect on phagocytic activity is noted that on laboratory animals infected, with injuries (area of 3.0 and $16.3 \mathrm{~cm}^{2}$ ) but nonionized (lots S1L5, S2L9) was observed a trend of increasing absolute number of phagocytic PMN; analog - at animals without infection but subjected to negative air ionization 15,000 particles $/ \mathrm{cm}^{3}$ (lot S1L2).

Under the negative and positive air ionization of 230,000 particles $/ \mathrm{cm}^{3}$ concentration on without injuries and uninfected animals and those with skin injuries infected with Staph. aureus was found significantly reduced values (lots S2L3 and S3L4) or a downward trend of these values (lots S2L7 and S3L8) of the absolute number of PMN phagocytic cells.

Killing Effect values of phagocytized microorganisms (the destruction of microorganisms) by PMN phagocytic cells (figure 15) were found maximum (in the control group data) to the WR from the control lot (S2L1), to those without injury but subject to negative air ionization of 15,000 or 230,000 particles $/ \mathrm{cm}^{3}$ concentration (lots S1L2 and S2L3), with infected injuries 3 days after infection and no ionization (lot S1L5) or infected injuries and subjected negative air ionization 15,000 particles / $\mathrm{cm}^{3}$ (lot S1L6). Of the experimental animals with infected injuries and inflammatory developed process (after 10 days of inflammation) (lot S2L10) and those with infected and uninfected injuries subjected to negative air ionization of about 230,000 particles $/ \mathrm{cm}^{3}$ (lot S2L7) or with infected and uninfected injuries subjected to positive air ionization of about 230,000 $/ \mathrm{cm}^{3}$ concentration, were observed significantly reduced values or a declining trend of Killing Effect.

The evaluation of oxygen-dependent bactericidal function of PMN granulocytes (oxidative metabolism of phagocytes) investigated by NBT test (tetrazolium test-nitroso-Blau) - the concentration of positive formasan cells from white Wistar rats blood of different experimental groups is shown in figures 4 and 5 .

According to available data, the relative (\%) and absolute (NX10 * $9 / 1$ ) values of the PMN formasan positive cells number from NBT test on WR in the experiment varied depending on the presence of inflammatory and infectious process and on the air ionization applied value, but were mostly high.

Significantly high values, both relative (\%) and absolute (NX10*9/L) were found at WR from group 3 with injuries of $3,0 \mathrm{~cm}^{2}$, infected but unionised (lot S1L5), with infected injuries of 16.3 $\mathrm{cm}^{2}$ and $20.1 \mathrm{~cm}^{2}$ (evaluated at 10 days after infection) but unionized (S2L9 and S2L10 lots).we also should note that on laboratory animals from these groups with different surface injuries, infected but unionized (S2L10, S219 and S1L5 lots) has been found the highest concentration of positive formasan PMN cells $(\mathrm{P}<0.05)$.

Of experimental WR the presence of injuries with different surface infected but subject to negative air ionization of 15,000 or 300,000 particles $/ \mathrm{cm}^{3}$ (lots S1L6 and S2 L7) and those with infected injuries subject to positive air ionization (S3L8) was observed an improvement (only a slight tendency to increase) of relative (\%) and absolute (NX10* $9 / 1$ ) number of formasan positive PMN cells compared with controls and significantly lower compared to animals from lots with injury and infection but unionized (S2L10 and S2L9 lots). Similarly, insignifiant increased were concentrations values of formasan positive cells of animals without injury and without infection, subject to negative air ionization of 15,000 particles $/ \mathrm{cm}^{3}$ (lot S1L2); application of negative air ionization of 230,000 particles $/ \mathrm{cm}^{3}$ was mentioned by a substantial decrease of formasan positive PMN cells in the blood $(\mathrm{P}<0.05)$.

Of experimental animals with uninflamed injuries subject to positive air ionization of 230,000 particles $/ \mathrm{cm}^{3}$ (lot S3L4) were not observed significant changes in the concentration of formasan positive PMN cells and those with inflamed injuries (lot S3L8) - was found a tendency to increase both the relative $(\%)$ as well as the absolutely (NX10*9/1) number of formasan positive cells in the blood.

To characterize the immune status has a particular significance the assessment of relative (\%) and absolute (NX10 * $9 /$ l) concentration of lymphocyte populations and subpopulations and their activation properties (blast transformation) under the action of mitogen.

It is noteworthy that on investigated WR were not found significant variations of relative concentration (\%) of T-lymphocytes in the blood, the existing deviations integrating in the standard values of deviation.

Figure 6 presents the results of concentration $T$ lymphocytes evaluation (after test E-RFC/CLFR) in absolute values (NX10*9/L). It is of interest the WR with skin inflamed injuries, without air ionization (lot S2L9), has been a significant increase of T-lymphocyte cells expressed in absolute value $(5.31+/-0.62 \times 10 * 9 / \mathrm{L}, \mathrm{P}<0.05>$ 0.01 ), which may be due to the development of an acute infectious-inflammatory process and the immune response to infection 
Figure 1.

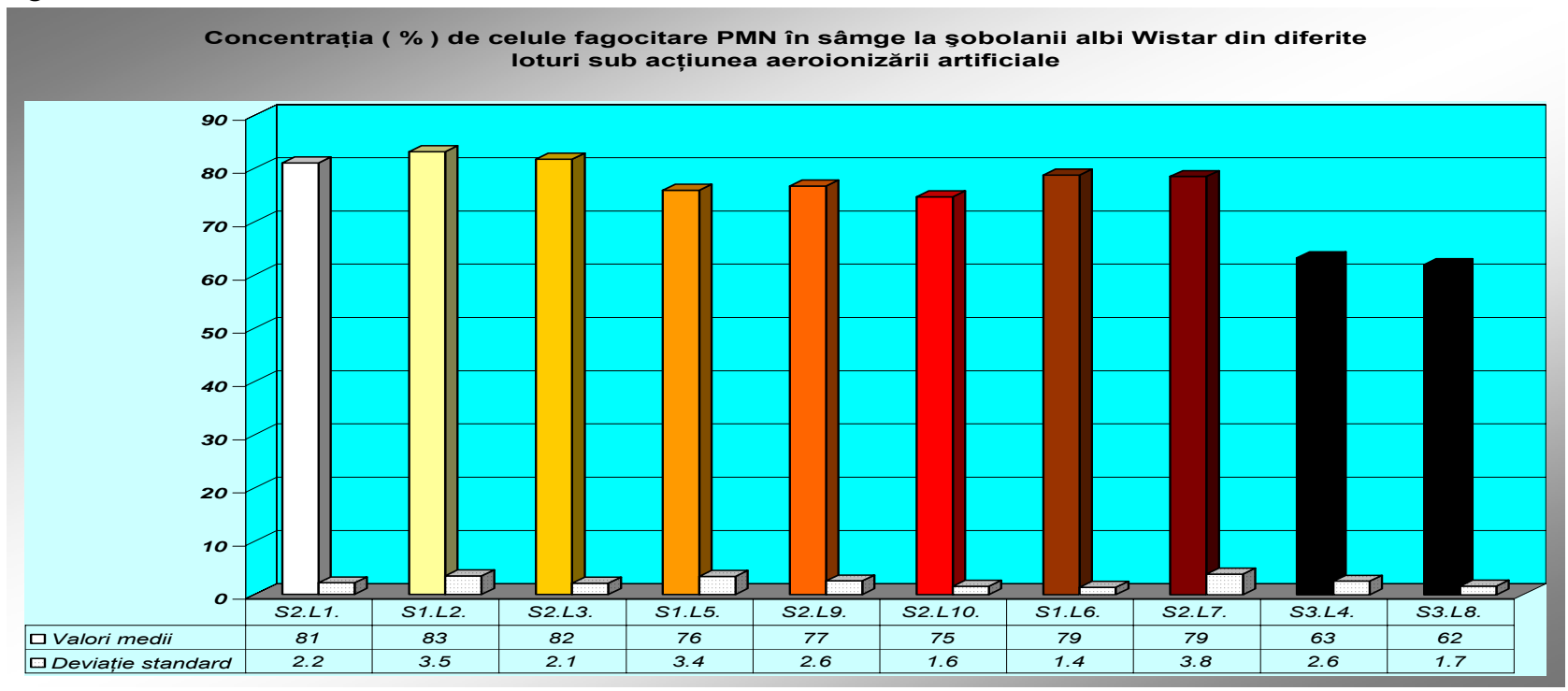

Figure 2.

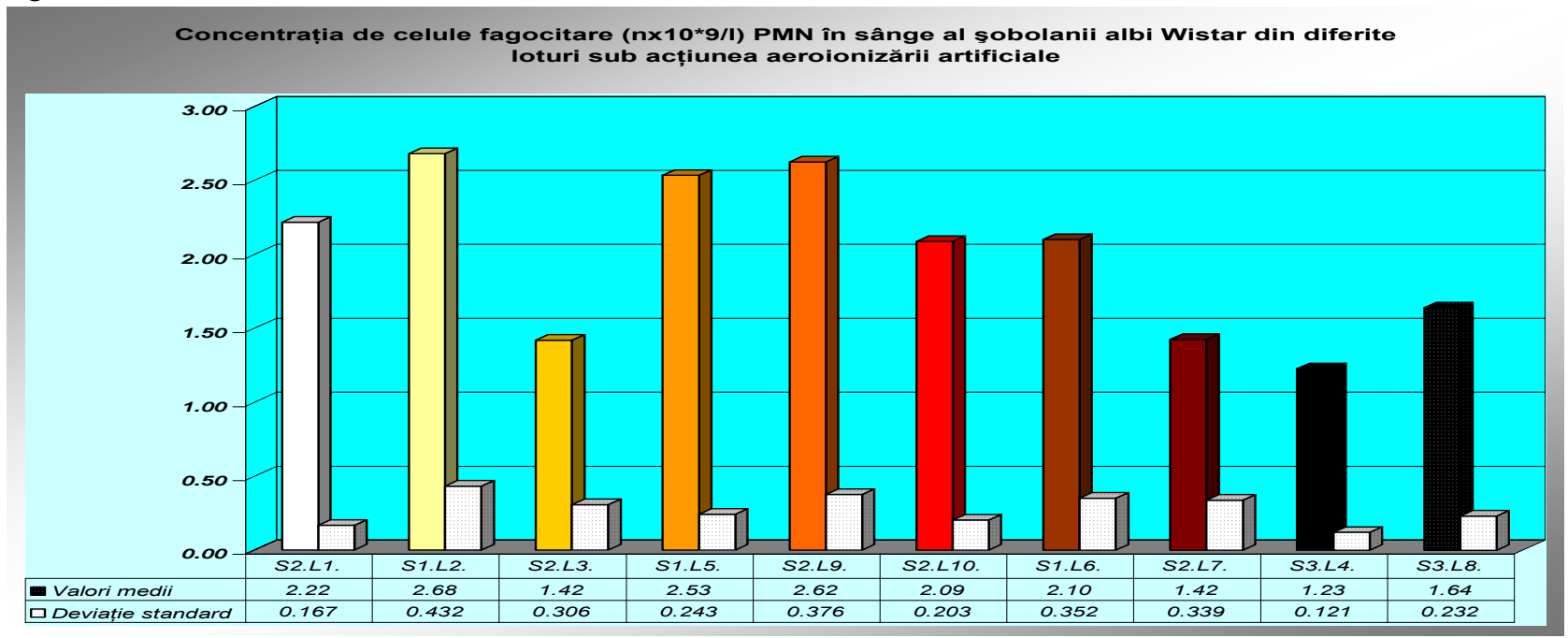

Figure 3.

Efectul Killing asupra celulelor microbiene (\%) din fagocitele PMN sangvine la şobolanii albi Wistar sub acțiunea aeroionizării artificiale

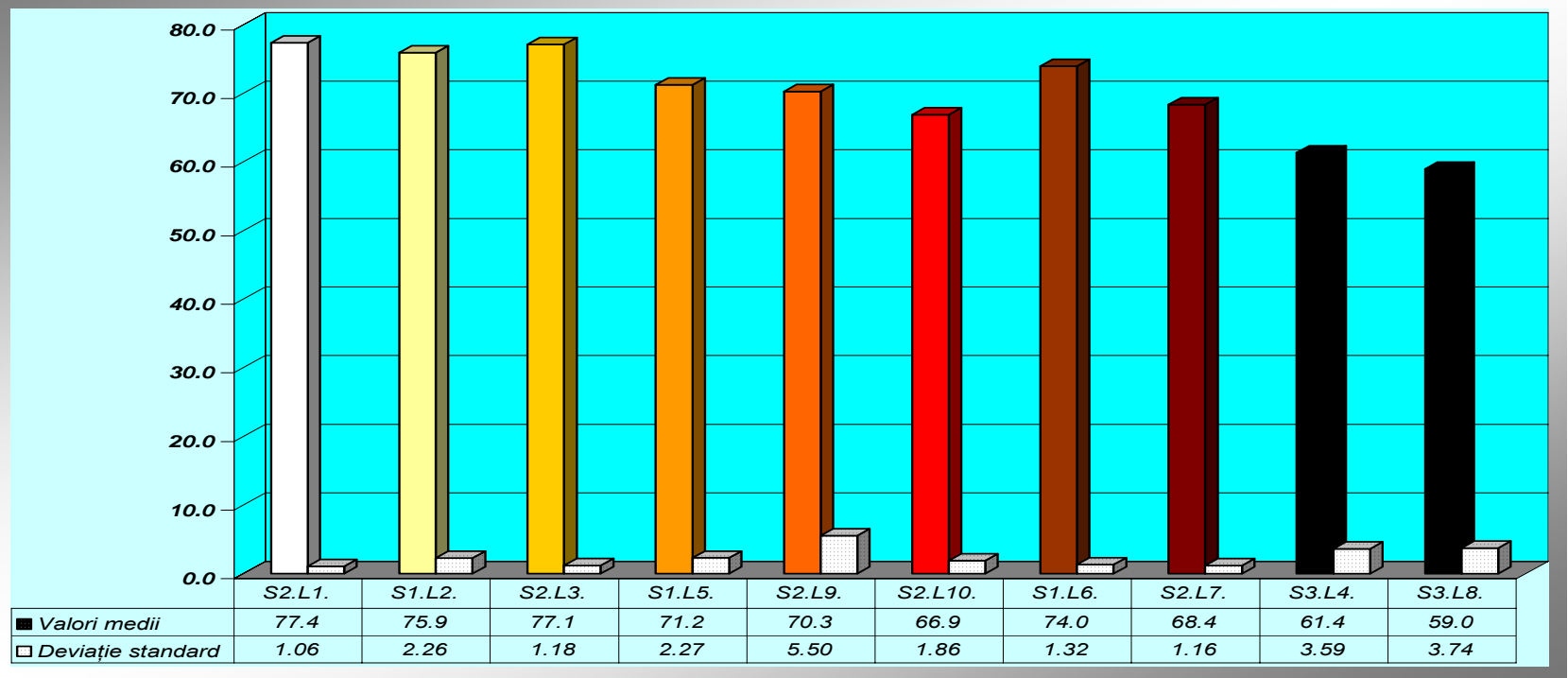


Figure 4.

Concentrația ( \% ) de celule PMN formazan pozitive sangvine în testul NBT la şobolanii albi Wistar din diferite loturi sub acțiunea aeroionizării artificiale

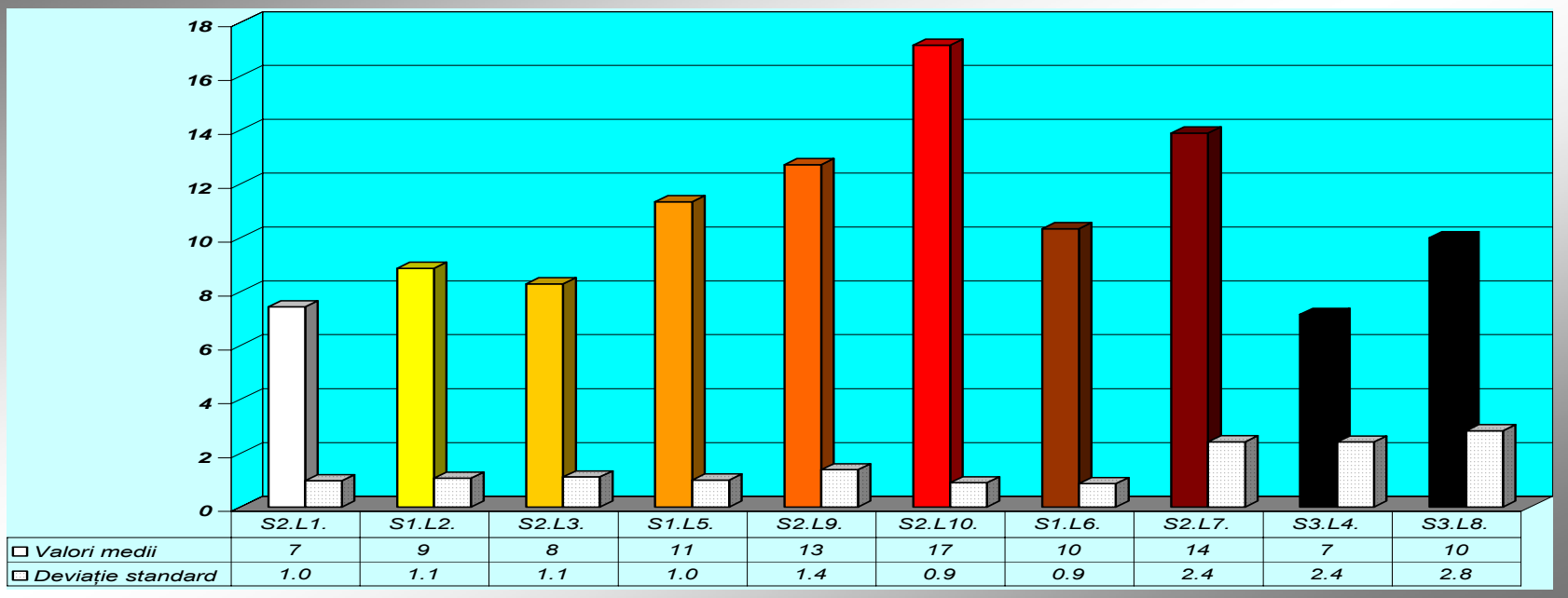

Figure 5.

Concentrația de celule (nx10*9/I) PMN formazan pozitive sangvine în testul NBT la şobolanii albi Wistar din diferite loturi sub acțiunea aeroionizării artificiale

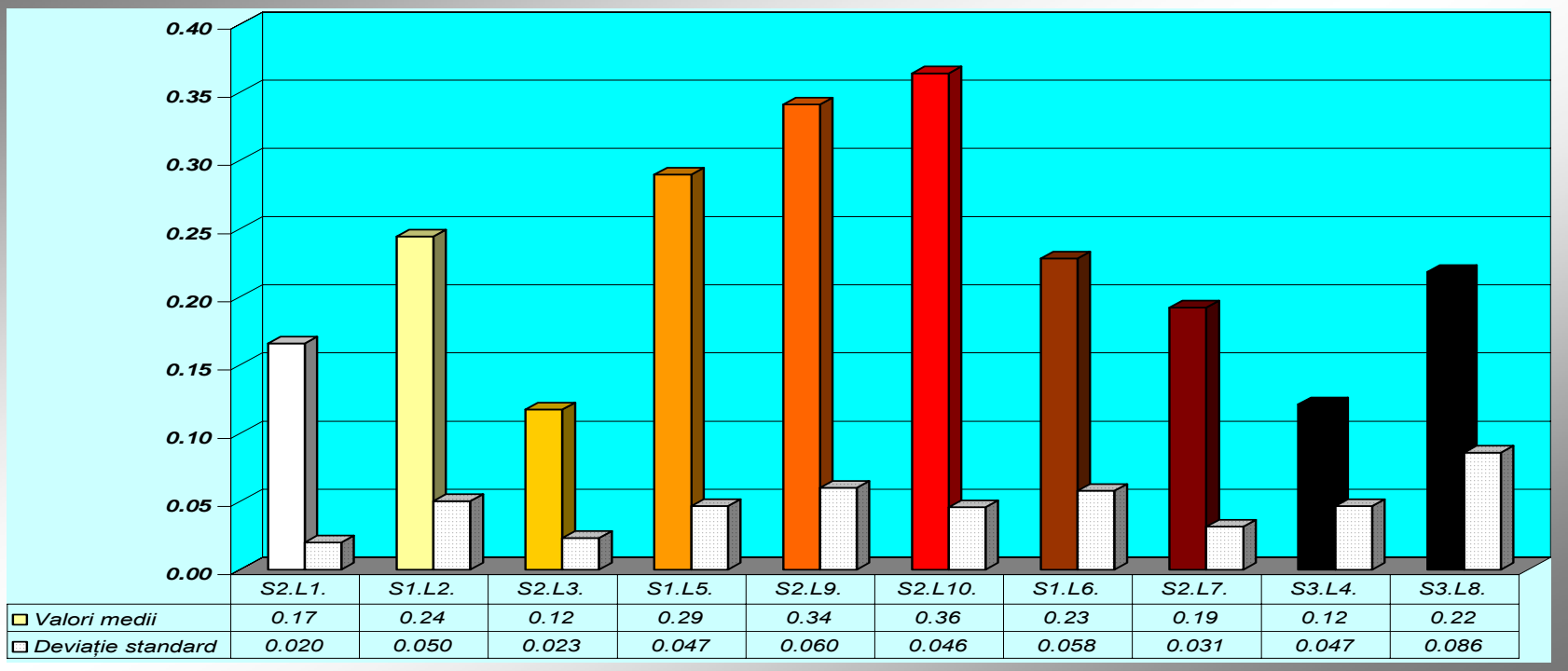

Figure 6.

Concentrația absolută $(\mathrm{n} \times 10 * 9 / 1$ sau $n \times 10 * 6 / \mathrm{ml})$

de limfocite $T$ (testul E-RFC) în sânge la şobolanii albi Wistar din diferite lotiri sub acțiunea aeroionizării artificiale

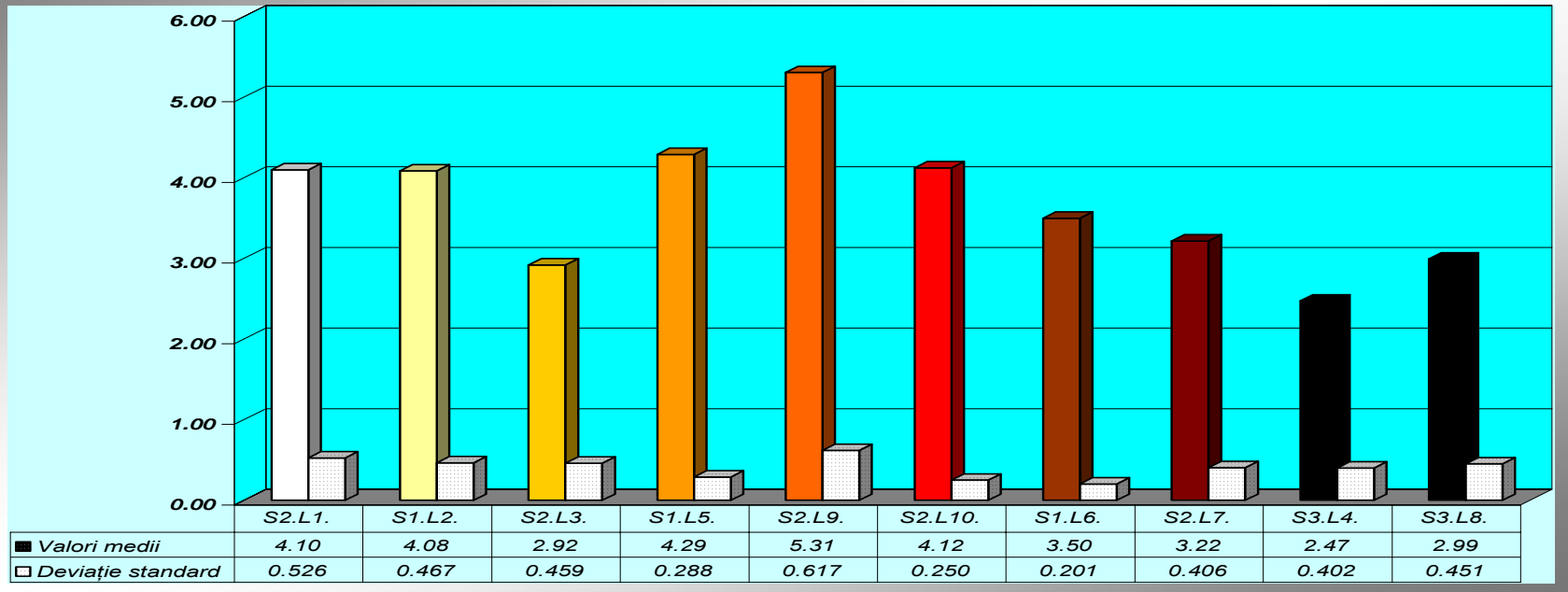


Of WR with no injuries and those with inflamed injuries from lots subject to negative air ionization of about 230,000 particles $/ \mathrm{cm}^{3}$ (lots S2L3 and S2L7) and subject to the same maximal values of positive ionization (lot S3L8) where observed some trends of decreasing absolute concentrations of $\mathrm{T}$ lymphocytes.

The analysis of data obtained showed that on the animals from control and experimental lot results were not found significant changes in their relative concentration (\%) of T-helper lymphocytes (E$\mathrm{RFC} / \mathrm{CLFR}, 29^{\circ} \mathrm{C}$ ), being observed some changes of absolute concentrations (NX10*9/L) of these cells.

Figure 7 presents the T- helper lymphocytes concentration of investigated WR.

Thus, a significant increase of the absolute number of lymphocytes T-helper took place at WR with inflamed skin injuries, unionised (lot S2L9); a significant decrease - on animals subjected to maximum positive air ionization of about 230,000 particles $/ \mathrm{cm}^{3}$ (lot S3L8) $(\mathrm{P}<0.05)$ and the tendency of decreasing the absolute concentration of these blood cells - of animals without injury and those with inflamed injuries from lots subject to negative air ionization of about 230,000 particles / $\mathrm{cm}^{3}$ (lots S2L3 and S2L7).

Figures 8 and 10 present the results of $\mathrm{T}$ suppressor lymphocytes concentrations in the blood (T lymphocytes - T lymphocytes E-RFC/CLFR test $29^{\circ} \mathrm{C}$ ) from experimental WR .

According to these data just for WR lots with uninflamed injuries and subjected to positive air ionization of about was found a tendency of decreasing of relative concentration (\%) of $\mathrm{T}$ suppressor lymphocytes. Of animals with or without injuries, infected or uninfected, unionized or subjected to negative air ionization of 15,000 or $230,000 / \mathrm{cm}^{3}$ were not mentioned significant changes.

Of WR with skin inflamed injuries, unionized (lot S2L9) was found an increasing trend of absolute number $(\mathrm{NX10} * 9 / 1)$ of $\mathrm{T}$-suppressor lymphocytes, of animals subjected to maximum positive air ionization of 230,000 particles $/ \mathrm{cm}^{3}$ (lot S3L8 ) - was found a significantl decrease ( $\mathrm{P}>$ $0.05<0.1)$ and of animals without injuries and with inflamed injuries from lots subject to negative air ionization of about 230,000 particles $/ \mathrm{cm}^{3}$ (lots S2L3 and S2L7) - the tendency of decreasing the absolute concentration of these blood cells.

Mathematical ratio (ratio index subpopulations cell)

"T-helper lymphocytes / suppressor Tlymphocytes" has changed slightly, suggesting a prevalence of T-helper cell concentration on the concentration of T-suppressor lymphocytes.
Figures 11 and 12 present the lymphcytes $\mathrm{T}$ cytotoxic concentration ( $\mathrm{T}$ lymphocyte thermostable at $45^{\circ} \mathrm{C}$ degrees).

The preseted data indicate that under the positive air ionization action of 230.000 particule $/ \mathrm{cm}^{3}$, on WR with uninfeted (lot S3L4) and infected (lot S3L8) injuries there was a significant increase ( $P$ $<0.05>0.01)$ of the relative number (\%) of cytotoxic lymphocyte cells ( $\mathrm{T}$ lymphocytes thermostable at $45{ }^{\circ} \mathrm{C}$ degrees). At WR with and without injuries and infection subjected to negative air ionization of 15.000 or 230.000 particles/ $\mathrm{cm}^{3}$ concentrations of cytotoxic $\mathrm{T}$ lymphocytes - were not significantly different, these deviations are within standard deviations.

Concentrations of T-cytotoxic lymphocyte cell expressed in absolute values (NX10*9/1) were raised at WR with infected injuries without ionization (lot S2L9) and those with infected injuries subjected to positive air ionization of 230,000 particles $/ \mathrm{cm}^{3}(\mathrm{P}>0.05<0.01)$; the trend of decreasing of absolute number of these blood cells was observed on animals without injuries and uninfected, and those with infected injuries and subject to negative air ionization of 230,000 particles $/ \mathrm{cm}^{3}$.

Concentrations of T-cytotoxic lymphocyte cell expressed in absolute values (NX10*9/1) were high at WR with infected injuries unionized (lot S2L9) and those with infected injuries subjected to positive air ionization of 230,000 particles $/ \mathrm{cm}^{3}$ ( $\mathrm{P}>0.05<0.01)$; the trend of decreasing the absolute number of these blood cells was observed on animals without injuries and uninfected, and those with infected injuries subject to negative air ionization 230,000 particles $/ \mathrm{cm}^{3}$.

The activation value of T-lymphocyte cells in vitro under the action of a mitogen are the functional property of these experimental WR lots. Figures 13 and 14 preseny the results of the lymphocyte transformation test in blasts (TTLB) cells in vitro activation of lymphocytes with phytohaemagglutinin.

From these data it was found that both the relative $(\%)$ and the absolute (NX10*9/L) concentration values of lymphocytes transformer blast were reduced in the blood of WR with infected injuries subjected to negative air ionization of about 230,000 particles / $\mathrm{cm}^{3}$ (lot S2L7) and those with uninfected injury (lot S3L4) and those with infected injury subjected to positive air ionization of about 230,000 particles / $\mathrm{cm}^{3}$ (lot S3L8).

He was mentioned the tendency of decreasing relative number (\%) of transformer blast cells on laboratory animals with infected injuries and infectious-inflammatory process lasting 10 days (lot S2L10) and absolute number (NX10*9/L ) of 
lymphoblasts from animals subjected to negative air ionization of about 230,000 particles $/ \mathrm{cm}^{3}$.

It also noted that of animals with intact injuries (lot S2L9) and inflammatory acute infectious process Figure 7.

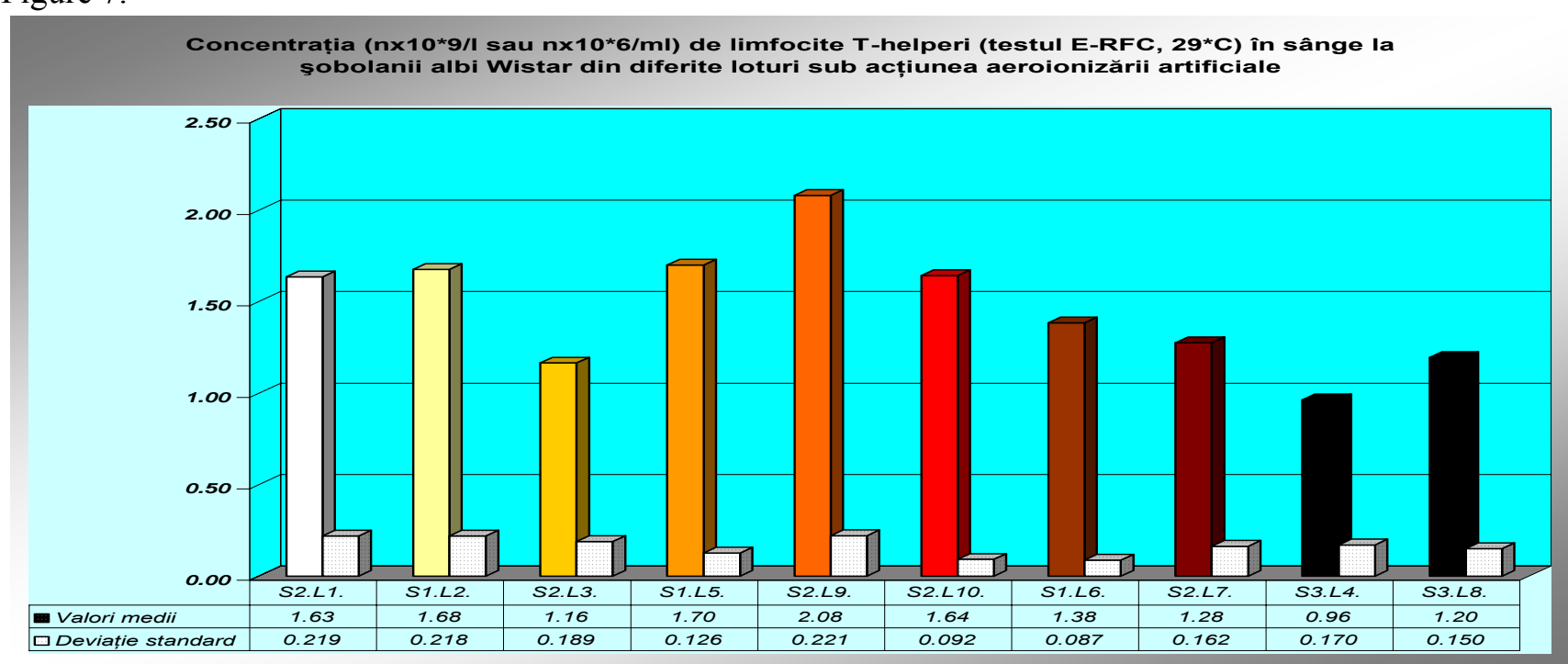

Figure 8.

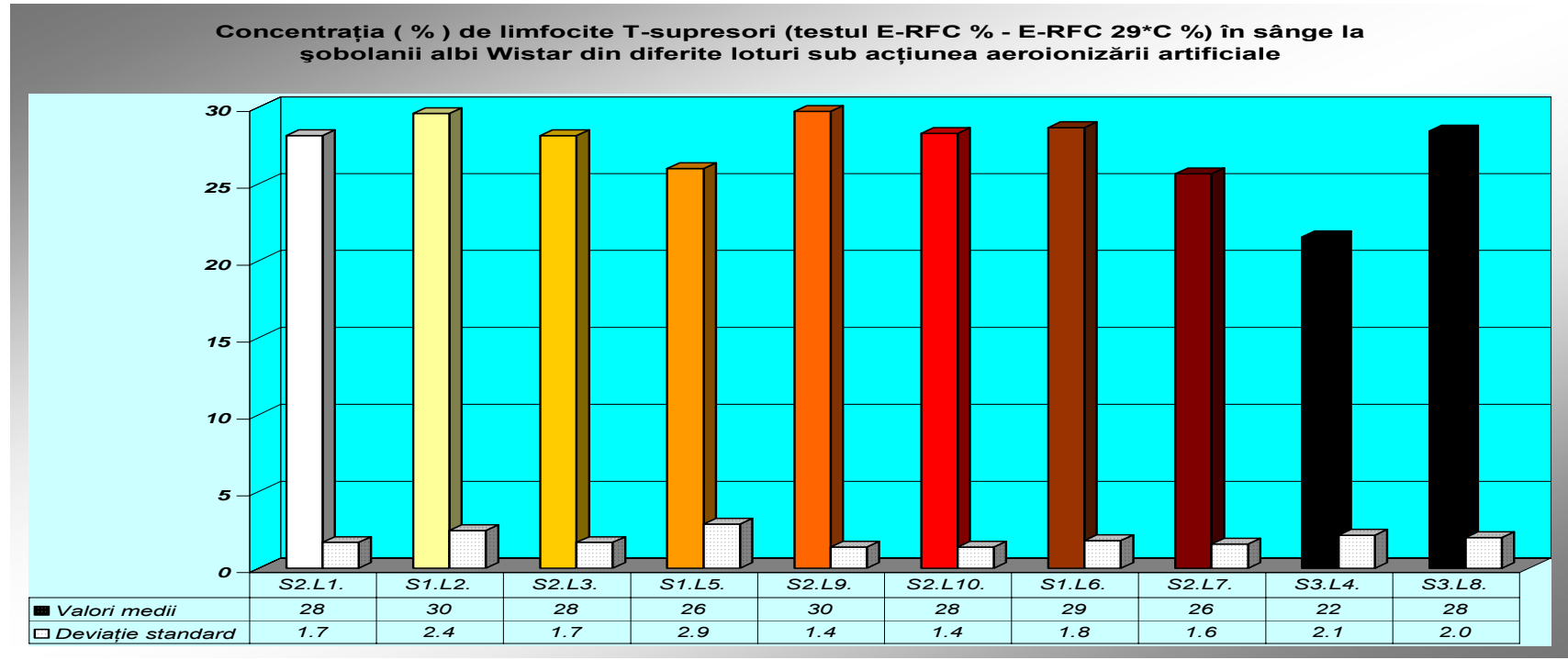

Figure 9.

Concentrația absolută $\left(n \times 10^{*} 9 / /\right.$ sau n×10*6/ml) de limfocite T-supresori (testul E-RFC - E-RFC $29^{*} \mathrm{C}$ ) în sânge la şobolanii albi Wistar din diferite loturi sub acțiunea aeroinizării artificiale

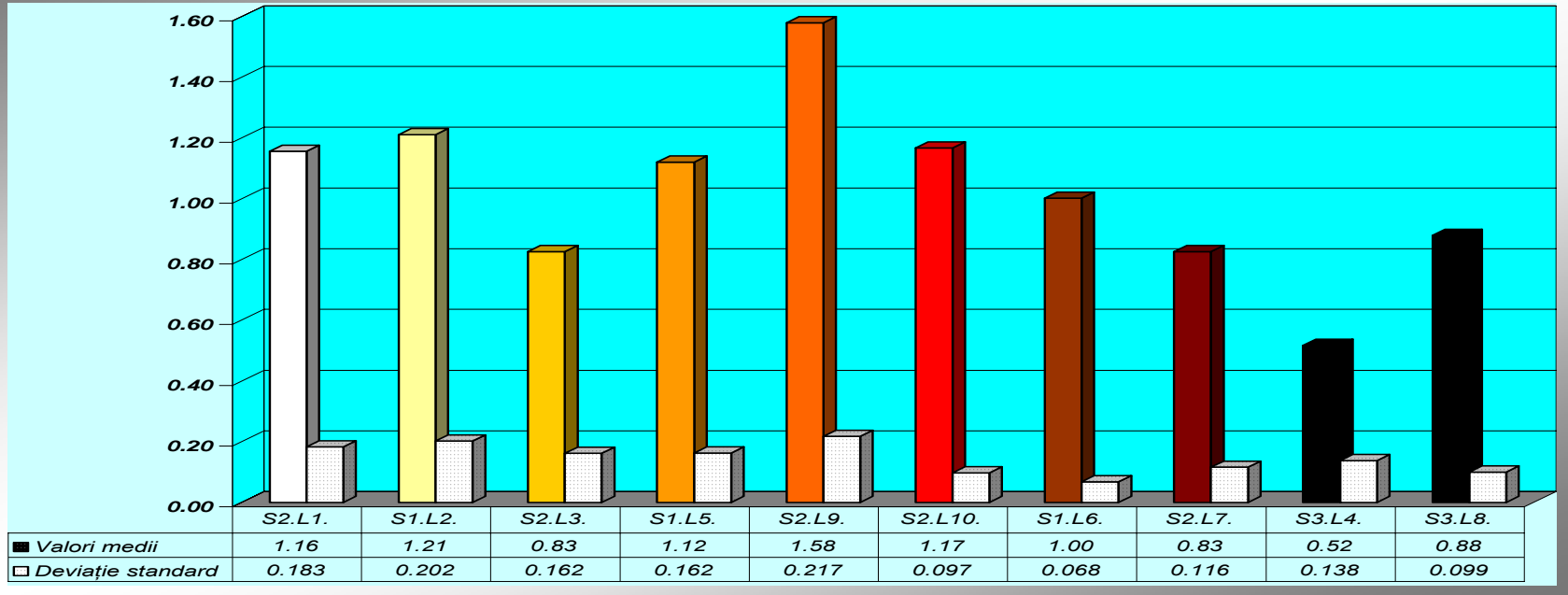


Figure 10. Valoarea raportului subpopulațiilor limfocitelor T-helperi / T-supresori (E-RFC 29*C / E-RFC -
E-RFC $29^{*}$ C) în sânge la şobolanii albi Wistar din diferite loturi sub acțiunea aeroionizării artificiale

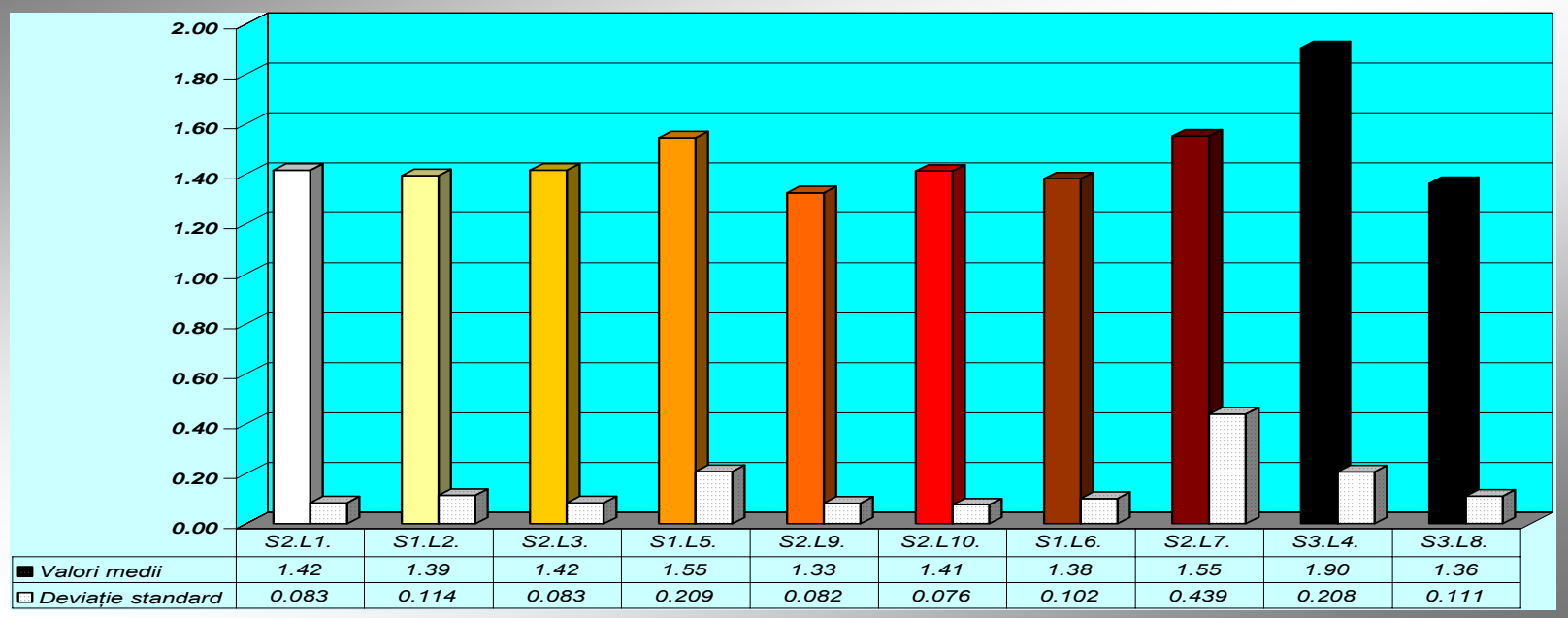

Figure 11.

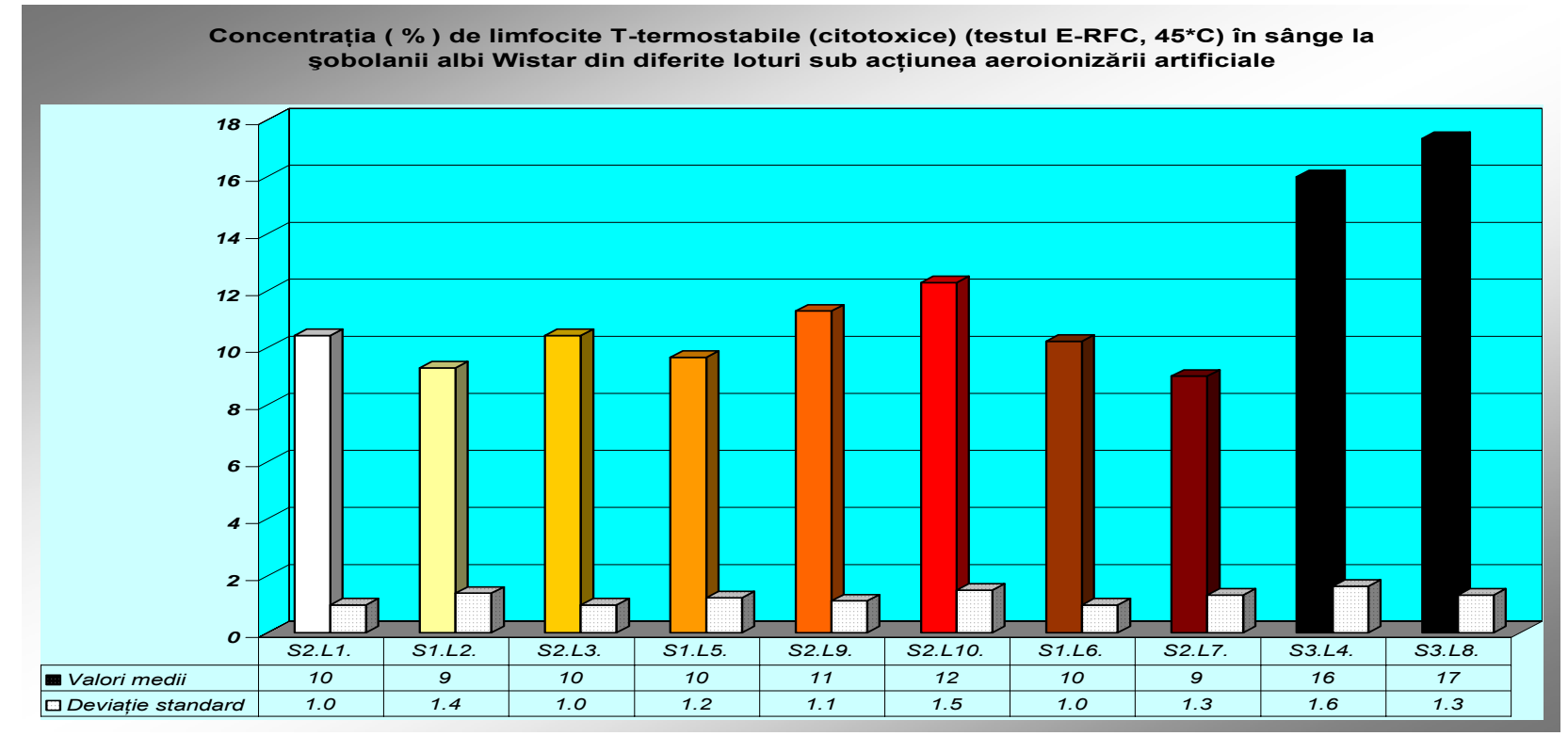

Figure 12.

Concentrația absolută $(n \times 10 * 9 / I$ sau $n \times 10 * 6 / \mathrm{ml})$ a limfocitelor T-termostabile (citotoxice) (testul E-RFC, $45^{\star} \mathrm{C}$ ) în sânge la şobolanii albi Wistar din diferite loturi sub acțiunea aeroionizării artificiale

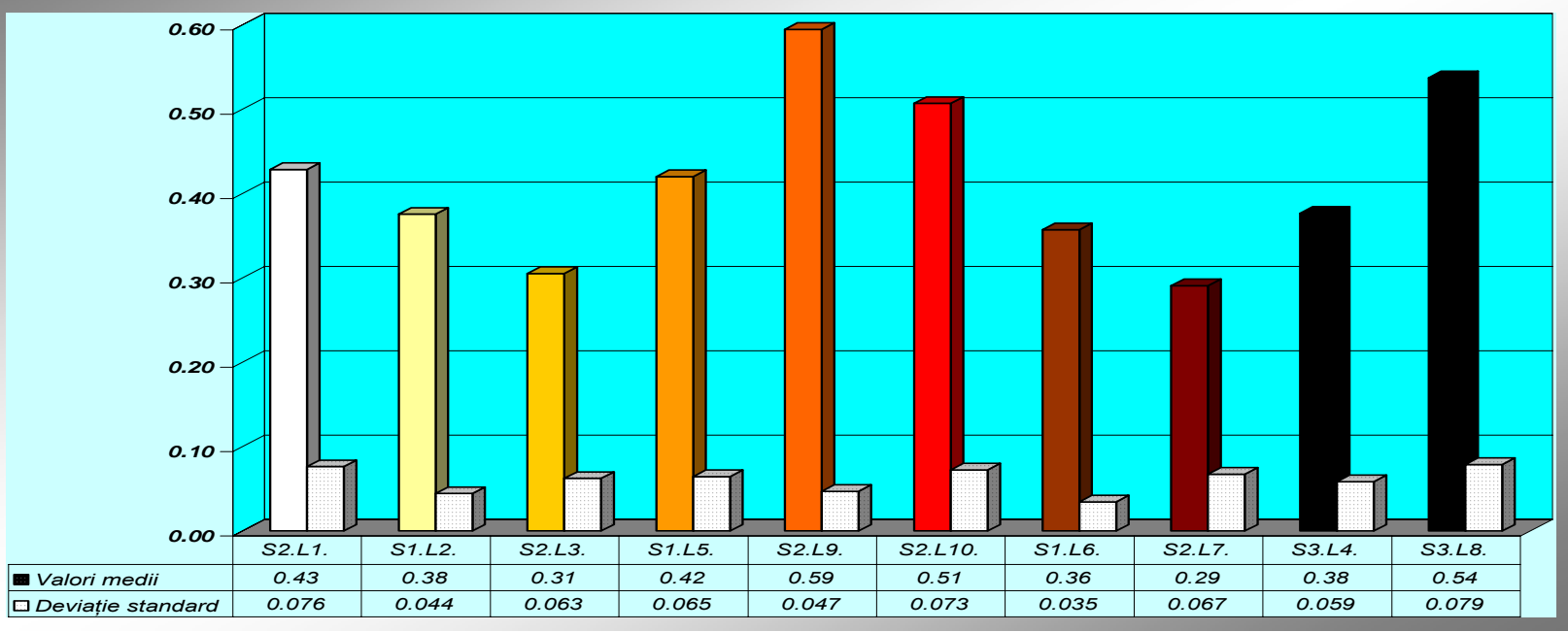


Figure 13.

Concentrația ( \% ) de limfocite T blasttransformatoare (activate la contactul cu mitogenul fitohemaglutinină) (testul de transformare blastică a limfocitelor sangvine in vitro) la şobolanii albi Wistar sub acțiunea aeroionizăriii artificiale

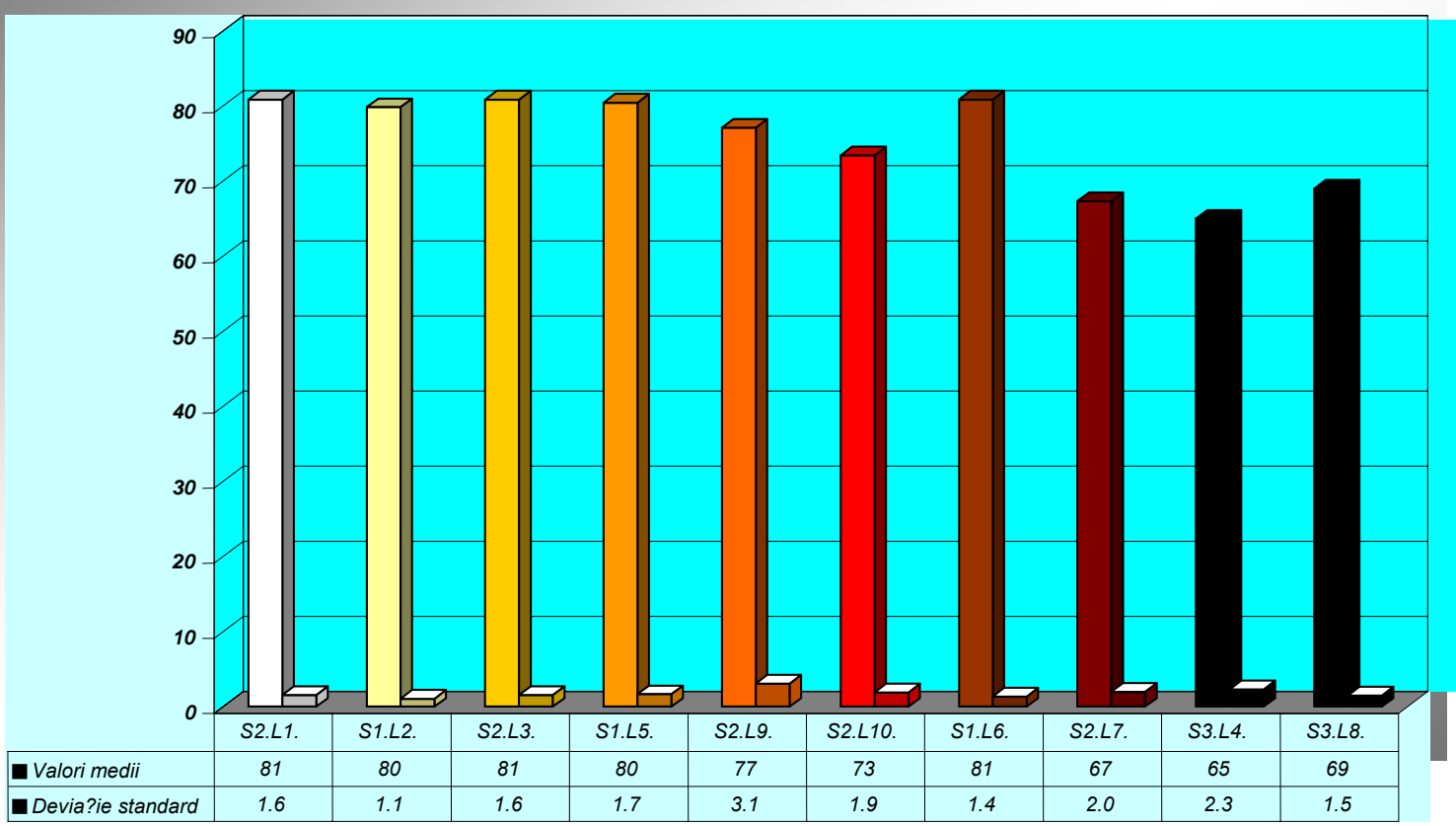

Figure 14.

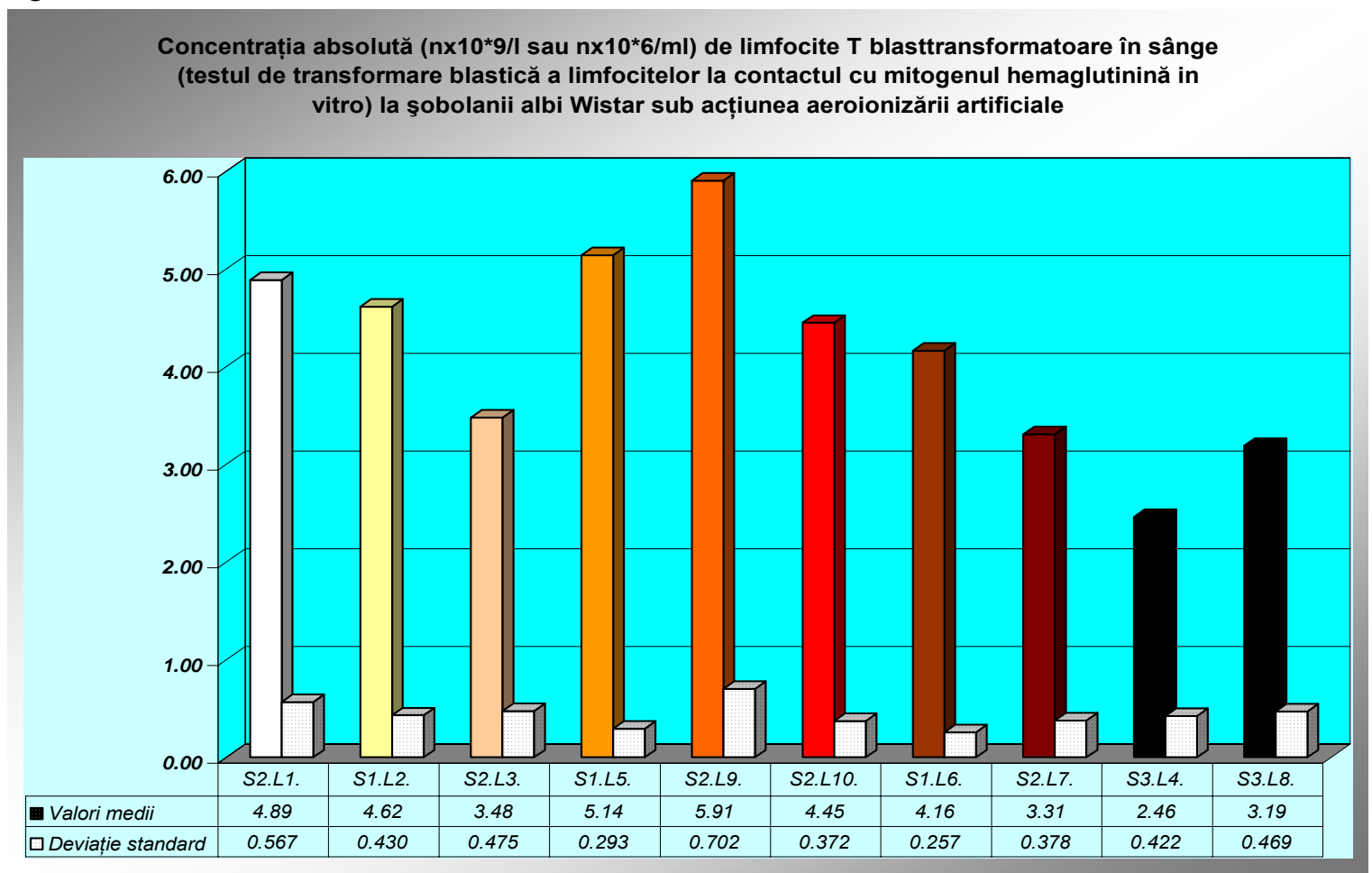




\section{DISCUSSION AND CONCLUSIONS}

Analysis of the presented results highlights the effect of negative values of air ionization of about 15,000 particles $/ \mathrm{cm}^{3}$ and 230000 particles $/ \mathrm{cm}^{3}$ on nonspecific_factors of body resistance of white Wistar rats (without inflammatory infectious skin process, induced experimentally on investigated WR lots).

Of experimental WR subjected to negative air ionization of 15,000 particles / $\mathrm{cm}^{3}$ was observed a stimulating tendecy of some components of the phagocytosis process including a increase of the absolute number of phagocytic PMN.

Under the action of negative air ionization of 230,000 particles $/ \mathrm{cm}^{3}$ concentration at WR were found significantly decreased of the number values of phagocytic PMN, which indicate the suppression effect of high air ions concentration. Is interesting to note that both the action of concentration of 15,000 particles $/ \mathrm{cm}^{3}$ and 230,000 particles $/ \mathrm{cm}^{3}$ at lots of animals without infectious-inflammatory effect was observed high value of Killing effect of phagocytic PMN on phagocytized microorganisms. Under the action of $230,000 / \mathrm{cm}^{3}$ particles concentration, on experimental laboratory animals was observed and a substantial decrease in the number of positive formasan PMN cells in the blood compared with controls and other experimental lots. These data indicate a stimulation of bactericidal effect of phagocytes (phagocyte concentration is reduced) and oxygen-dependent bactericidal function of these.

Based on the analysis results we should note the role of nonspecific factors of resistance against infection in the acute infectious-inflammatory skin process (over 3 days) and longer (after 10 days) achieved experimentally on WR.

Thus, with the development of infectiousinflammatory process at WR with infected injuries but unionized was observed the tendency of decreasing relative number of phagocytic PMN and an increase in absolute value which is due to high concentration (NX10*9/L) of leukocytes in blood - response to infection and acute inflammation.

Although the total (absolute) of phagocytes number did't decrease (has been found just the tendency to decrease of relative value of these PMN cells as has been noted) in the first three days on animals with infected injuries and those with inflammatorydeveloped process, (after 10 days of infection) was highlighted the decreasing and the trend of decreasing of microorganisms phagocytized number in cytoplasm of PMN phagocytosis, which involves damage of microorganisms properties by that phagocytic blood cells.
It is significat that at 3 days after injuries infection was found a Killing effect stimulation and after 10 days its reduction and a substantial increase of the number of formasan positive cells (the NBT test), which confirming the minimize of the "destruction" effect of phagocytized microorganisms with extension of infectious-inflammatory process

The phagocytosis and nitroso-blau-tetrazolium (NBT) tests analysis at experimental WR, indicates the presence of laboratory experimental animals with infected injuries and induced infectious inflammatory skin process a nonspecific defense response of body against infection during the acute phase (3 days) and phagocytic properties and the "destruction" minimizing of phagocytized microoorganism and oxygen-dependent bactericidal function of PMN granulocytes, particularly during the longer-lasting inflammatory process (after 10 days infection / inflammation of skin injuries).

Applying of negative air ionization of 15,000 particles $/ \mathrm{cm}^{3}$ concentration on laboratory animals with skin injuries Staph.aureus infected didn't significantly changed the relative (\%) and absolute (NX10 * 9/L) concentration of phagocytic PMN cells and the number of phagocytized microoorganisms has stimulated considerable Killing effect of PMN phagocytic cells on phagocytized microorganisms. Relative and absolute number of PMN formasan positive cells had a growth trend and is therefore slightly lower their oxygen-dependent bactericidal function, which may be due to the presence of injuries and inflammatory infectious skin process

Under the negative air ionization of 230,000 particles $/ \mathrm{cm}^{3}$ concentration, on animals infected with Staph. aureus were not found significant changes in relative concentration (\%) of phagocytic PMN cells and was observed the trend of decreasing of them absolute number (NX10 $* 9 / \mathrm{L}$ ) , reducing the Killing effect of phagocytes, and tendency to increase of relative and absolute of formasan positive PMN cells.

These results indicate the possibility of significant damage (decrease) of the phagocytosis process on WR infected and inflamed injuries subjected to negative air ionization with very high concentrations (about 230000 particles / $\mathrm{cm}^{3}$ ).

Of the experimental animals in presence of injuries with different surface infected but subject to negative air ionization of 15,000 or 300,000 particles $/ \mathrm{cm}^{3}$ (lots S1L6 and S2 L7) and those with infected injuries subject to positive air ionization (S3L8) was observed an improvement trend (a slight tendency to increase) of the relative $(\%)$ and absolute (NX10* $9 / \mathrm{L})$ number for PMN formasan positive cells compared with controls and significantly lower compared with animals from 
lots with injury and infection but unionized (lots S2L10 and S2L9).

Regarding to the positive air ionization action, it is significant to note that under the action of concentration of 230,000 particles $/ \mathrm{cm}^{3}$ at WR in the experimental lots that was found a suppression effect on the phagocytosis process, which was manifested by decreasing the number of phagocytic PMN cells in the blood of laboratory animals with infected injuries, and significantly reduce of the Killing effect. of laboratory animals with inflamed injuries have mentioned the tdendency of suppression oxygen-dependent bactericidal function of PMN blood cells.

At WR investigated were not found significant variations of (\%) T lymphocytes (E-RFC-CLFR), the lymphocyte subpopulations - T-helper lymphocytes (E-RFC-CLFR $29^{\circ} \mathrm{C}$ ), T-suppressor lymphocytes (E-RFC - $29^{\circ} \mathrm{C}$ E-RFC) relative concentration in the blood, existing deviations integrates in the standard values. In the presence of infectious-inflammatory process (the infected and inflamed injuries) in the acute phase has been mentioned a significant increase of T-lymphocyte absolute number (NX10*9/L), and of absolute value of T-helper lymphocytes and the tendency to increase the absolute number of $\mathrm{T}$-suppressor lymphocytes.

In WR blood without injuries inflamed subject to negative air ionization about 230,000 particles / cm 3 was observed the trend of decreasing $\mathrm{T}$ lymphocyte absolute concentration and of animals without injuries and those with inflamed injuriesthe tendency of decreasing the concentration of absolute T-helper and T-suppressor. Under the positive air ionization of about 230,000 particles / $\mathrm{cm}^{3}$ - was observed the trend of decreasing the absolute concentration of T-lymphocytes and a significant decrease in the absolute number of $\mathrm{T}$ helpers and T-suppressor.

Should be noted that the index report of cell subpopulations "T-helper lymphocytes / suppressor T-lymphocytes" wasn't subjected to significant changes, only a tendency to increase the value on experimental animals subjected to positive air ionization concentration of $230,000 / \mathrm{cm}^{3}$.

Of WR- with or without infected injuries subjected to negative air ionization 15,000 or $230,000 / \mathrm{cm}^{3}$ particles the relative values of the concentration of cytotoxic T-lymphocytes - (T lymphocytethermostat at 45 degrees $C$ ) weren't significantly changed. Under the positive air ionization action of 230,000 particles $/ \mathrm{cm}^{3}$ was reported a significant increase of relative and absolute number of cytotoxic lymphocyte cells, being observed the tendency of decreasing the absolute number of these blood cells on animals subjected to negative air ionization of 230,000 particles $/ \mathrm{cm}^{3}$.
It is noteworthy that some changes occurring as a result of the activation blastogenesis- $T$ lymphocytes process in vitro. Thus, both the relative (\%) and the absolute (NX10 * $9 / \mathrm{L})$ concentrations values of blast transformer lymphocytes were reduced at animals with infected inuries subjected to negative or positive air ionization of about 230,000 particles $/ \mathrm{cm}^{3}$. Reduction of the relative blast transformer cells number has been mentioned at animals with infected injuries and infectious-inflammatory process lasting 10 days, those with injuries inectate acute inflammatory and infectious process is observing an increasing trend of the blast transformer cells number in blood.

The results analysis allow to establish that both tests characterizing some non-specific resistance factors of the animal organism (phagocytosis, NBT test) and those of the lymphocyte immune system that characterizes the immune status were framed in the ionization normal limits with concentrations of about 15,000 particles $/ \mathrm{cm}^{3}$ ot Wistar white rats. Under the action of the same values of negative ionization was found a stimulation of different phases of phagocytosis both on animals without skin injuries and those with infected injuries and acute inflammatory-infectious process. So under the action of higher concentrations than natural, it was found that with faster regeneration of the infected and inflamed skin area occurred antibacterial mechanisms activation of blood cells neutrophils in the PMN phagocytosis (enhanced Killing Effect) and NBT tests .

The results indicate the possibility of (decrease) phagocytosis process damage at Wistar white rats with infected and inflamed injuries subjected to very high concentrations (negative and positive) of negative air ionization (about 230000 particles / $\mathrm{cm}^{3}$ ).

The $\mathrm{T}$ lymphoma system values weren't significantly changed by negative air ionization of about 15,000 particles $/ \mathrm{cm}^{3}$, but on the animals subjected to negative or positive air ionization of about 230,000 particles $/ \mathrm{cm}^{3}$ concentration appeared some drop in the concentration of $\mathrm{T}$ lymphocytes and T-helpers subpopulations, and decrease of the lymphocytes activation process (blast transformation), suggesting the possibility of suppression of some factors of the immune status to positive and negative maximal concentrations of air ionization.

Thus, from the cellular immunological investigations on the $\mathrm{T}$ lymphocytes system have found results that showing the presence of some changes of the lymphoma immune system parameters on experimental animals subjected to negative and positive air ionization of $2 \underline{30,000}$ particles $/ \mathrm{cm}^{3}$ concentration. 
The data are of interest both from practical and basis for research and indicate the need for studies development in this area.

*Results obtained in phase IV(Responsible- CPII

Dr.b. Simionca Iuri), Project Nr.466/2004 -

2007(Project Manager- Conf. Dr. fiz. Enache Liviu)

\section{BIBLIOGRAFIE SELECTIVĂ}

1. Ardelean I., Barnea M., Elemente de biometeorologie medicală, Editura Medicală, Bucureşti, 1972.

2. Bach F., Hirschorn K. Lymphocyte interaction, a apotential histocompatibilitz test in vitro. "Exptl. Cell. Res", 1963, 32, 592.

3. Bach M., Braschler S.R. (1970). Isolation of subpopulations of lymphocytes cells by the use of isotonicaly balanced solutions of Ficoll. Exp. Cell. Research, 61, p.387-396.

4. Boyum A. (1961) . Isolation of leucocytes from human blood. Futher observations. Scand. J. Clin. Lab. Invest., 21, (supl.97), p.31.

5. Breton J., Breton M., 1994, Phénomènes ioniques atmospheriques, micropollution et climats: des lois physiques á leur application, Climat et Santé, G.D.R., 102, CNRS, 11, p. 55 - 74.

6. Bâră C. (2002). Esențial de imunologie. Bucureşti, 222 p.

7. Boulatov, P. C. (1968). “Traitement de l'asthme bronchique par l'aeroionisation négative." In: Bioclimatology, Biometeorology and Aeroionotherapy (R. Gualtierotti, I. H. Kornblueh, and C. Sirtori, eds.) Carlo Erba Foundation Publ., Milano, p. 104.

8. Cernuşenko E.F., Kogosova L.S., Gonciarova S.I., Tâşko N.A. Simionca Iu.M., Pop I.L., şi al. (1988).: Metode unificate de investigații imunologice a bolnavilor $\hat{i n}$ etapele de terapie $\hat{\imath}$ spital şi ambulator.Recomendații metodice. Aprobate de Ministerul Sănătății al RSS Ucr., 26.04.1998, Kiev, 18 p. 9. Danon A., şi Sulman F. G., 1969, Ionising effect of winds of ill repute on serotonin metabolism, Biometeorology 4 (Suppl. to Int. J. Biometeor.) 4, Part II, p. $135-136$.

10. Enache L. şi Andrişan C., 1990, Determinări privind influența aeroionizării asupra poluării aerului, I.A.N.B., Lucrări ştiințifice, seria E, XXXIII, Îmbunătățiri funciare, Bucureşti, p. 35.

11. Enache L., 1999, Ionizarea aerului şi efectele sale biologice, Sănătatea plantelor, nr. 16 (9), p.34, Bucureşti.

12. Enache L. , Biofizică, vol. 2. Editura Universității "Spiru Haret", Bucureşti, 2005.

13. Enache L., Filipescu C., Simionca Iu. (Ghe.) and al.: Natural and artificial air ionization in underground spaces - an environmental factor with therapeutic potential. 14th International Congress of Speleology. Athens-Kalamos, 21-28 August 2005. Congress Proceedings, CD, Folder FULL PAPERS, Microsoft Word Document 189 Full Paper, p. 1-5.

14. Enache Liviu, Filipescu C., Simionca Iu. (Ghe.) şi al. (2005).: Ionizarea naturală şi artificială a aerului din spații subterane - factor de mediu cu potențial terapeutic. Revista de Recuperare, Medicină Fizică şi Balneoclimatologie, Societatea Română de medicină fizică şi Recuperare, Bucureşti, 2005, Nr.3-4, p. 136141.

15. Gabay JE. (1988) Microbicidal mechanisms of phagocytes. Curr.Opin. Immunol. , 1, p.36

16. Gates D. M., 1980, Biophysical Ecology, Springer - Verlag, New-York.

17.

$\mathrm{Ge}$

orgescu Ileana, Enache Liviu, Simionca Iu. Şi al. (2005).: Studii privind acțiunea aeroionilor asupra procesului infecțios inflamator cutanat indus la animalele de laborator. Al 36-lea Simpozion de morfologie normală şi patologică, Sesiunea Anuală a Institutului Naţional „Victor Babeş” cu participare internaţională. Institutul Naţional de Cercetare-Dezvoltare în Domeniul Patologiei şi Ştiinţelor Biomedicale „Victor Babeş" . Bucureşti, 26-28 Octombrie 2005, C.43, p.51.

18.

$\mathrm{Gu}$

idelines for Collection of Blood from Experimental Animals. University of Minnesota, USA. HTML Document, 2006.

19. Jaskowski, J. and Mysliwski, A. (1986). "Effect of air ions on healing of wounds of rat skin." Exp. Pathol. 29:113-117.

20. Jones D.P. and al. Effect of long-term ionized air treatment on patients with bronchial asthma

Departments of Medicine and Medical Electronics, St. Bartholomew's Hospital, London ECIA 7 BE. Thorax 1976, 31, pp. 428-432.

21. Hematological Values for Long Evans Rats. Hematological Values for Wistar-Kyoto Rats.

TACONIC. ANTECH diagnosis, 10 Executive Blvd. Farmingdele. Nz 11735. HTML Document, 2006.

22. Kornblueh, I. H. (1973). "Artificial ionization of the air and its biological significance." Clin. Med. 69:282-286.

23. Krueger A.P., Smith R.F.and Ing Gan Go The action of air ions on bacteria - i. protective and lethal effects on suspensions on staphylococci in droplets .J. Gen. Physiol., 41: pp. 359-381 (1957).

24. Krueger A.P., Smith R.F. The physiological significance of positive and negative ionization of the atmosphere. in mans dependence on the earthly atmosphere. Proceedings of the First International Symposium on Submarine and Space Medicine. Edited by Karl E. Schaefer, 1958, The MacMillan Company, pp. 356-369.

25. Krueger A.P., Smith R.F.The biological mechanisms of air ion action. Reprinted from the Journal of General Physiology, January, 1960 Vol. 43, No. 3, pp. 533-540 (U.S.A.).

26. Krueger A.P., 1972, Are air ions biologically significant? A review of a controversial subject, Int. J. Biometeor., 16, p. 313 - 322.

27. Krueger, A. P (1976). Biological effects of ionization of the air on animals Progress on Biometeorology: The Effect of Weather and Climate on Animals. Chapter 5, Section 1, Swets \& Zeitlinger, B.V., Amsterdam, pp. 155-162 (1976).

28. Krueger, A. P (1982). Air ions as biological agents - facts or fancy? PART 1 
Immunology and Allergy Practice. Vol. IV (4): July/August: 63 (1982).

29. Krueger, A. P (1982) Air ions as biological agents - facts or fancy? PART II Immunology and Allergy Practice. Vol. V (5): Sept./Oct.: 46 (1982).

30. Krueger, A. P. (1985). "The biological effects of air ions.” Int. J. Biometeor. 29:205-206.

31. Laza, V. (1996). "The Stimulation of the Man and Animal Reactivity upon Negative Air Ionisation." (In Romanian) Thesis, Cluj-Napoca, Romania.

32. Livanova, L. M., Elbakidze, M. G., and Airapetiants, M. G. (1999). "Effect of the short-term exposure to negative air ions on individuals with autonomic disorders." (In Russian) Zh. Vyssh. Nerv. Deyat. 49:760-767.

33. Makela Paavo and al. Studies on the effects of ionization on bacterial aerosols in a burns and plastic surgery unit. 0022-1724/79/0097-1978 s01. 001979 Cambridge University Press.

34. Minehart J. R. and al. The effect of artificially ionized air on post operative discomfort.

35. Amer. J. Phys. Med., 1961, 40, 56 -62.

36. Marin, V., Moretti, G., and Rassu, M. (1989). "Effects of ionization of the air on some bacterial strains.” Ann. Ig. 1:1491-1500.

37. Olinescu A., Dolganiuc Angela (2001). Imunologia practică în clinică şi experiment. Bucureşti, $276 \mathrm{p}$.

38. Pierson, D.L. 1993. Microbiology. In: Space Physiology and Medicine, 3rd edition (Nicogossian, A.E., Huntoon, C.L. and Pool, S.L., Eds.) Philadelphia, Pennsylvania: Lea and Febiger, pp. 157-166.

39. Puggina Rogato Gustavo, Elite Luciano. Leukocytes profile of rats (Rattus norvegicus albicans, Wistar). Submited to chronic resistence exercise. FAPESP / grant no 00/01804-6. Universitode Estadual Paulista. Abstracts. Volume 18, n. 1, HTML Document 2006.

40. Simionca Iu.M. (1989): Metodă de determinare a populațiilor şi subpopulaţiilor de limfocite în microvolume ale suspensiei de celule mononucleare. În volumul : « Noutăți în diagnostica de laborator a bolilor interne (în perioada acută şi de recuperare a bolii) ». Rezumatele comunicărilor celui de al IV-lea congres al societăţii ştiinţifice republicane de medicilaboranți.Voroşilovgrad, 1989, p. 423-424. (în 1.rusa). 41. Simionka J.M. (1997) : Curative Effect of Speleotherapy in the Pathogenesis of InfectionInflammatory and Allergic Diseases. The International Conference : Protection and Medical Utilization of Karst Environment. Slovac Environment Agency. Banska Bystrica, 3-5 June, 1997, P.68-70.

42. Simionca Iu. Elements of medical and biological mechanism of speleotherapy in salt mines. International Symposium of Speleotherapy, September 23-26, 1999, Czech Republic, Zlate Hory, 1999.

43. Simionca Iu. (Ghe.), Enache L., Guțu Emilia, Teodoreanu Elena, Aniței Lidia. (2005).: Microclimatul cu aerosol salin şi regimul ionizării aerului (saline, litoralul Mării Negre) factori de sanogeneză a căilor respiratorii. Al 28-lea Congres Național de Medicină Fizică şi de Recuperare. Societatea Română de medicină Fizică şi de Recuperare, Poiana Braşov, 02-05 noiembrie 2005, Volum de rezumate, rezumat poster P73, p.95.

44. Soyka F. şi Edmonds A., 1977, The Ion Effect, Dutton \& Co. Publ. N.Y., 181 pp, Sulman, F.G. (1976), Health, Weather and Climate, Karger, Baswel, p.160.

45. Taylor, G.R., Graves, R.C., Ferguson, J.K., Brockett, R.M. and Mieszkuc, B.J. 1977. Skylab environmental and crew microbiology studies. In: Biomedical Results from Skylab (Johnston, R.S. and Dietlein, L.F., Eds.)

46. Tchijevski A. L. Les phénoménes électrodynamiques dans le sang et le moyen de les diriger. Ed. Le Francois 1963, Paris. UCHA UBADE R., UCHA UBADE M. Significado biológico de la aeroionización, su relación con las neurohormonas, Semana Méd., 1963, 122, 1399.

47. Vassiliev L. L. The physiological mechanism of aeroions . Amer. J. Physio., 1960, 39, 124-128.

48. Verzar F. Continuous record of atmospheric condensation nuclei and of their pretention in the respiratory tract. Reprinted from the review Geofisica Pura E Applicata - Milano

Vol. 31, pp. 183-190 (1955)

49. Williams, D.L., Climie, A., Muller, H.K. and Lugg, D.J. 1986. Cell-mediated immunity in healthy adults in Antarctica and the Antarctic. Journal of Clinical and Laboratory Immunology 20:43-9. 